\title{
クリタマバチ輸入天敵チュウゴクオナガ コバチの放飼実験
}

\section{(4) 放飼後 6 年間の経過}

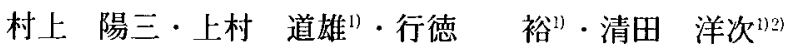 \\ (九州大学農学部・11熊本県果樹試験場)
}

\begin{abstract}
Colonization of imported Torymus (Syntomaspis) sinensis KaMIJO (Hymenoptera: Torymidae) parasitic on the chestnut gall wasp (Hymenoptera: Cynipidae). (4) Trends in host densities and parasitization during six years following release. Yôzô MURaKamI, Michio Uemura"), Yutaka GYOUTOKU ${ }^{1)}$ and Yoji KiYOTA')2) (Faculty of Agriculture, Kyushu University, Fukuoka 812. ') Kumamoto Fruit Tree Experiment Station, Matsubase, Kumamoto 869-05. 2) Present address: Kumamoto Agricultural Experiment Station, Kaminogo, Kumamoto 861-41)
\end{abstract}

Trends in gall densities and parasitization of the chestnut gall wasp, Dryocosmus kuriphilius Yasumatsu in an experimental orchard of Kumamoto Prefecture following the introduction of an imported parasitoid, Torymus (Syntomaspis) sinensis KaMIJo were reviewed, and the interim results were discussed. During six years following its release, gall-formed buds fluctuated at a high density level greatly because the parasitization rate remained relatively low. Two possible reasons of low parasitization rate were discussed. One was that the parasitoid might suffer a high mortality caused by hyperparasitism, and the other was that the established parasitoid population did not increase due to its low female ratio.

著者らは，岡田利承・志賀正和雨氏が1981年11月訪中 の際に持ち帰った中国河北省遵化県産のクリタマバチ Dryocosmus kuriphilus YASUMATSU のゴールのうち1,249個 の分与を受けた。それらのゴールから翌年 3 月23日ー 4 月 4 日に羽化したチュウゴクオナガコバチ Torymus (Syntomaspis) sinensis KaMuO の倠成虫257頭と雄成虫232 頭を 4 月 1 日と 5 日の 2 回に分けて能本県菊池郡大津町 の米田孝一氏所有のクリ園に放飼した（村上・清田， 1983）。放飼 2 年後の 1984 年春に, 放飼園とその隣接園 で前年12月にサンプリングしたゴールからチュウゴクオ ナガコバチが 5 頭羽化し，本種の定着を確認した（村上 ら，1985）。著者らはその後も放飼園と隣接園で調查を 続けてきたが，放飼後 6 年間の経過をとりまとめたので 報告する。

奇生蜂の輸入に当たって種々便宜をはかられた中国側 関係者ならびに機関, ゴールを分与して下さった農水省 果樹試験場虫害研究室, ならびに試験ほ場を快く提供し 実験にご協力いただいた米田孝一氏にお礼申し上げる。

2）見在 熊本県農業試駼場

\begin{abstract}
調 查 方 法
\section{1. ゴール着生率の調查}

每年 4 月下旬から 6 月上旬の間に 1 回, 放飼園内の 12 本の調査樹 (品種: 筑波) から, 長さ $30 \mathrm{~cm}$ 以上の充実し た結果母枝を任意に10本ずつ選び，ゴール着生芽数と健 全芽数を調査した。両者の和に対するゴール着生芽数の 百分率をゴール着生率とし，ゴール密度の一つの指標と した。
\end{abstract}

\section{2. 寄生率の調査}

毎年 5 月下旬から 6 月上旬の間に 1 回, 放飼園内の前 記調查樹以外の樹から採集したゴールを，実体顕微鏡下 でカッターナイフを用いて解剖し寄生率を調査した。調 查したゴール数は，1982年74個，1983年100個，1984年 200個，1985年405個，1986年400個，1987年410個，1988 年409個であった。虫房内から検出された寄生蜂幼虫の うち，チュウゴクオナガコバチとクリマモリオナガコバ

$千$ Torymus (Syntomaspis) beneficus YASUMatsu et KamiJo は、形態的特徴によって識別できないが，これらの 2 種 
と他の寄生蜂は容易に区別できるので, 検出された寄生 蜂をTorymus (Syntomaspis) spp. とその他の奇生蜂に分け て記録した。

ゴールから摘出した寄生蜂の幼虫と蛹をすべてゼラチ ンカプセル (Eli Lilly \& Co. 社製, No.0) に1頭ずつ 入れ，成虫を羽化させて種名を同定した。Torymus (Syntomaspis) spp.の幼虫はすべてカプセル内で死亡した ので, 後述する越冬寄生蜂の羽化調查から得られたチ工 ウゴクオナガコバチとクリマモリオナガコバチの羽化個 体数の比を用いて, 両種の寄生個体数を推定し寄生率を 求めた。

\section{3. 秋に羽化する寄生蜂の調查}

福岡市油山で探集したクリタマバチのゴールから秋に もある種の寄生蜂が羽化することが知ら机ているので （村上，1977），本放飼園で秋に羽化する笴生蜂を調查 する目的で，1983年 9 月13日に213個のゴールを採集し た。そのうち100個を解剖し, 残りを福岡市内の九州大 学農学部生物的防除研究施設ほ場の百葉箱内に放置して 寄生蜂を羽化させた。

\section{4. 越冬寄生蜂の羽化調査}

乾枯ゴール内で越冬し翌春羽化する寄生蜂を調查する 目的で，毎年12月中旬から翌年 1 月下旬までの間に 1 回， 放飼園の 12 本と隣接園の 4 本の調查樹から, 各樹約 50 個 のゴールを採集し, 九州大学生物的防除研究施設ほ場の 百葉箱内に放㯰して寄生蜂を羽化させた。

\section{結 果と考 察}

チュウゴクオナガコバチ放飼後のゴール着生率と寄生 率の推移はFig. 1 に示すとおりである。ゴール着生率 は本放飼園のクリ樹（品種：筑波）では約43 78\%の間 で変動しており, 寄生蜂全種による寄生率は寄主密度の 変動にやや遅れて約13～23\%の範囲で変動している。し かし寄生の大部分は土着寄生蜂によるもので, チュウゴ クオナガコバチによる寄生はあまり増加しておらず, 放 飼 5 年後の 1988 年に至っても0.7\%という低い值に過ぎ

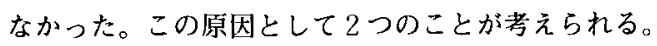

ひとつは二次寄生蜂の影響の可能性である。Table 1 は，1982年から1988年にかけて本放飼園のクリタマバチ のゴールから羽化した寄生蜂の種類と羽化時期を示した ものである。導入種のチュウゴクオナガコバチと土着種 の14種の寄生蜂が確認された。このうちチュウゴクオナ ガコバチとクリマモリオナガコバチは年 1 世代の生活環 を示すが，その他の寄生蜂は多化性である（MURAKAMI， 1981）。クリタマバチの幼虫又は蛹に寄生したこれら多 化性寄生蜂の成虫は, クリタマバチの羽化期と前後して

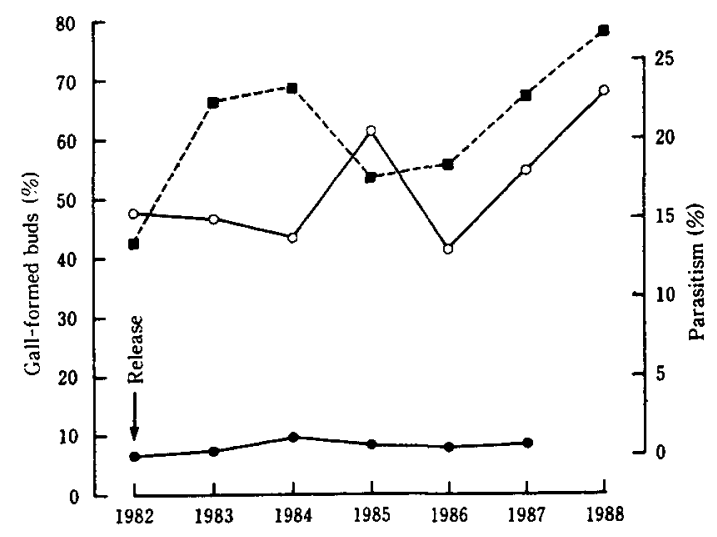

Fig. 1 Annual fluctuations of percentage of gall-formed buds (broken line) and percentage parasitism of the cynipid by all the species of parasitoids (solid line with open circles) and by Torymus (Syntomaspis) sinensis (solid line with closed circles) in an experimental orchard of Kumamoto Prefecture.

Table 1 Parasitoids emerging from Dryocosmus kuriphilus galls collected from an experimental orchard in Kumamoto Prefecture from 1982 to 1988.

\begin{tabular}{|c|c|c|c|}
\hline \multirow{2}{*}{ Parasitoids } & \multicolumn{3}{|c|}{ Emergence periods } \\
\hline & June-July & Sept-Oct. & March-June \\
\hline Torymus (Syntomaspis) sinensis & & & $\mathrm{P}^{1}$ \\
\hline T. (S.) beneficus & & & $\mathrm{P}$ \\
\hline T. $($ Torymus $)$ geranii & $\mathrm{P}$ & & \\
\hline Megastigmus mpponicus & $\mathrm{P}$ & $\mathrm{H}^{\mathrm{t}}$ & \\
\hline M. maculipennis & $\mathrm{P}$ & $\mathrm{H}$ & \\
\hline Mesopolobus yasumatsui & $\mathrm{P}$ & & \\
\hline Ormyrus punctiger & $\mathrm{P}$ & & \\
\hline o. flavitibialis & $\mathrm{P}$ & & $\mathrm{H}$ \\
\hline Eurvtoma brunnuventris & $\mathrm{P}$ & & \\
\hline E. setigera & $\mathrm{P}$ & & $\mathrm{H}$ \\
\hline Sycophnla variegata & $\mathrm{P}$ & & \\
\hline Eupelmus urozonus & $\mathrm{P}$ & $\mathrm{H}$ & $\mathrm{H}$ \\
\hline Eupelmus sp. & $\mathrm{P}$ & & $\mathrm{H}$ \\
\hline Cynipencyrtus flavus & $\mathrm{P}$ & & \\
\hline Tetrastichus sp. & $\mathrm{P}$ & & $\mathrm{H}$ \\
\hline
\end{tabular}

${ }^{1} \mathrm{P}:$ Generation parasitizing host cynipid; $\mathrm{H}:$ Generation parasitizing hyperparasitically.

6ー7月にクリタマバチのゴールから脱出した（Table 1).

これらの多化性奇生蜂のうちクリノタカラモンオナカ コバチ Megastigmus nipponicus YasumatsU et KamIJO, オ オモンオナガコバチ Megastigmus maculipennis YASUMATSU et KAMIJO 及びクリタマヒメナガコバチ Eupelmus urozonus Dalman は9ー10月にもクリタマバチのゴールから羽 
Table 2. Number of specimens of different parasitoid species emerging from samples of withered galls of Dryocosmus kuriphlus collected in winter from an experimental orchard and an adjacent orchard, and percentage of Torymus (Sintomaspis) spp. parasitized by facultative hyperparasitoids.

\begin{tabular}{|c|c|c|c|c|c|c|c|}
\hline \multirow{2}{*}{ Year } & \multicolumn{2}{|c|}{$\begin{array}{l}\text { No. of Torvmus } \\
\text { (Syntomaspis) spp. }\end{array}$} & \multicolumn{4}{|c|}{ No. of facultative hyperparasitoids } & \multirow{2}{*}{$\begin{array}{l}\text { Estimated } \\
\text { percentage } \\
\text { parasitism }\end{array}$} \\
\hline & sinensis & beneficus & $\begin{array}{c}\text { Ormyrus } \\
\text { flavitibialis }\end{array}$ & $\begin{array}{l}\text { Eurytoma } \\
\text { setigera }\end{array}$ & $\begin{array}{l}\text { Eupelmus } \\
\text { spp. }\end{array}$ & $\begin{array}{l}\text { Tetrastichus } \\
\text { sp. }\end{array}$ & \\
\hline $1982 / 83$ & 0 & 9 & 0 & 0 & 3 & 0 & 23.1 \\
\hline $1983 / 84$ & 5 & 73 & 0 & 1 & 40 & 0 & 34.5 \\
\hline $1984 / 85$ & 6 & 35 & 0 & 1 & 11 & 0 & 22.6 \\
\hline $1985 / 86$ & 5 & 39 & 1 & 4 & 28 & 0 & 36.7 \\
\hline $1986 / 87$ & 2 & 24 & 0 & 1 & 12 & 0 & 33.3 \\
\hline $1987 / 88$ & 7 & 11 & 0 & 0 & 61 & 1 & 77.5 \\
\hline
\end{tabular}

化脱出した（Table 1)。またキアシタマヤドリコバチ Ormyrus flavitibialis YASUMATSU et KaMIJO,トゲアシカタ ビロコバチ Eurytoma setigera MAYR, クリタマヒメナガコ バチそそれ近縁の未同定種 Eupelmus sp., ヒメコバチ の一種 Tetrastichus sp. は, 翌春 4 月上旬から 6 月上旬に かけて乾枯ゴールから脱出した (Table 1)。

ASKEW（1975）は，イギリスのカシワ類にゴールを作 るタマバチ類をめぐる奇生蜂群集の研究によって, Syntomaspis（本報では Torymus 属の亜属として取扱った） と Eudecatoma（=Sycophila）の耐属の奇生蜂は単食性又は 狭食性で造瘦性タマバチにのみ寄生するが，Torymus （本報では Torymus 亜属として扱った），Megasiigmus， Mesopolobus, Ormyrus, Eurytoma, Eupelmus, Tetrastichus など の属の寄生蜂は多食性で，タマバチに奇生するだけでな く，二次・三次寄生などの高次寄生も行うことを明らか にした。

6ー7月にクリタマバチのゴールからクリタマバチと 多化性の寄生蜂が羽化脱出したあと,ゴール内に残って いるのはチュウゴクオナガコバチとクリマモリオナガコ バチの幼虫だけである。このことと ASKEW が述べたこ とから判断すると，秋と翌春ゴールから羽化したこれら の属の寄生蜂は, チュウゴクオナガコバチ又はクリマモ リオナガコバチに寄生した二次寄生又は三次笴生の個体 であろうと考えられる (Table 1)。

秋に羽化したこれらの笴生蜂によるクリマモリオナガ コバチとチュウゴクオナガコバチに対する寄生率は, 1983年 9 月に解剖した 100 個のゴールの調査結果から推 定した。検出された371虫房のうち, Torymus (Syntomaspis) spp.の生存幼虫は17虫房から，その他の奇生蜂の生存 幼虫は 7 虫房から発見された。後者がすべて Torymus (Syntomaspis) spp.の幼虫に寄生していたと仮定すれば, 寄生率は29.2\%と推定される。
Table 3. Number of females and males of Torumus (Syntomaspis) sinensis emerging from sample galls of Dryacosmus kuriphilus collected from an experimental orchard and an adjacent orchard, and the percentage of females.

\begin{tabular}{cccc}
\hline Year & Female & Male & Percentage of females \\
\hline $1983 / 84$ & 0 & 5 & \\
$1984 / 85$ & 2 & 4 & \\
$1985 / 86$ & 1 & 5 & 19.2 \\
$1986 / 87$ & 1 & 1 & \\
$1987 / 88$ & 1 & 6 & \\
\hline
\end{tabular}

次に越冬期における二次寄生蜂によるクリマモリオナ ガコバチとチュウゴクオナガコバチに詨する寄生率を， 乾枯ゴールから翌春羽化した奇生蜂の倜体数によって推 定した。この場合 Torymus (Syntomaspis) spp.の幼虫又は 蛹に対してすべての二次寄生蜂が単寄生し，かつ越冬中 の Torymus (Syntomaspis) spp. と二次寄生蜂の生存率が等 しいと仮定して寄生率を推定した（Table 2)。それによ ると, クリマモリオナガコバチとチュウゴクオナガコバ チに対する越冬期の奇生率は，年によって異なるが22.6 ～77.5\%の範囲で変動していることが明らかとなった。 とくにクリタマヒメナガコバチと Eupelmus sp. が重要で ある。

チュウゴクオナガコバチによる奇生率が放飼 5 年後に 至っても増加していないもう一つの原因は，定着後の低 い雌率にあると思われる。Table 3 は, 定着確認以降放 飼園と隣接園で採集されたゴールから羽化した本種の雌 雄別個体数を示したものである。放飼された中国産ゴー ルから羽化した本種の雌率は52.6\%で雌雄ほ注同数であ ったが, 定着後の性比は著しく雄に偏り，5年間の羽化

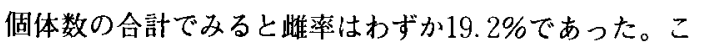
のように異常に低い脽率は, 放飼個体の大部分の雌が未 交尾であったために受精卵（雌卵）がわずかしか産みつ 
けられなかったことに起因するものと思われる。このこ とから, 寄生蜂の導入放飼に当たっては, 放飼雌の高い 交尾率を実現するよう細心の注意を必要とすることが示 唆された。

\section{引用 文 献}

1) ASKEw, R. R. (1975) Evolutionary Strategies of Parasitic
Insects and Mites (P. W. Price ed.). Plenum Press : 130-153.

2) 村上陽三 (1977) 今月の農薬 21(9):58-62。 3) MURAKAMI Y. (1981) J. Fac. Agr., Kyushu Univ. $25: 167-174$. 4) 村 上陽三・清田洋次（1983）九病虫研会報 29:155-157。 5) 村上陽三・上村道雄・行徳 裕 (1985) 九病虫研会報 31 : $216-219$.

(1989年5月 1 日 受領) 